\title{
Effect of Organic and Inorganic Fertilizers on Growth, Yield and Quality of Okra under Integrated Nutrient Management
}

\author{
B. Mishra ${ }^{1}{ }^{*}$, G.S. Sahu ${ }^{1}$, P. Tripathy ${ }^{1}$, S. Mohanty ${ }^{2}$ and S. Pradhan ${ }^{3}$ \\ ${ }^{1}$ Department of Vegetable Science, College of Agriculture, OUAT, \\ Bhubaneswar, Odisha-751003, India \\ ${ }^{2}$ Department of Soil Science, College of Agriculture, OUAT, Bhubaneswar, \\ Odisha-751003, India \\ ${ }^{3}$ Department of Plant Breeding and Genetics, College of Agriculture, OUAT, \\ Bhubaneswar, Odisha-751003, India \\ *Corresponding author
}

\section{A B S T R A C T}

\begin{tabular}{|l|}
\hline K e y w o r d s \\
$\begin{array}{l}\text { INM, Growth, Yield, } \\
\text { Quality, Neem oil } \\
\text { cake, Vermicompost } \\
\text { and Okra }\end{array}$ \\
\hline Article Info \\
\hline $\begin{array}{l}\text { Accepted: } \\
\text { 04 July 2019 } \\
\text { Available Online: } \\
\text { 10 August } 2019\end{array}$ \\
\hline
\end{tabular}

\begin{abstract}
A field experiment was conducted at the instructional farm of Krishi Vigyan Kendra Jajpur, Odisha during 2015 to study the "Effect of integrated nutrient management on growth, yield and quality of okra", variety-Pusa A4. From the experiment it was observed that application of RDF $(75 \%)+(25 \%)$ $\mathrm{N}$ through neem oil cake $\left(\mathrm{T}_{7}\right)$ produced maximum plant height $(131.40 \mathrm{~cm})$, internode length $(8.02 \mathrm{~cm})$, fruit length $(11.96 \mathrm{~cm})$, maximum number of fruits per plant $(14.42)$, individual fruit weight $(14.89 \mathrm{~g})$, yield per plot $(13.29 \mathrm{~kg})$, Yield per ha. $(9.49$ ton) where RDF was 110:50:80 NPK $\mathrm{kg} / \mathrm{ha}$. Whereas, maximum number of nodes per plant $(22.42)$, maximum fruit girth $(5.86 \mathrm{~cm})$ were found in $\left(\mathrm{T}_{5}\right)$ where $\mathrm{RDF}(75 \%)+(25 \%) \mathrm{N}$ through vermicompost were applied. Application of $\mathrm{RDF}(75 \%)+(25 \%) \mathrm{N}$ through neem oil cake $\left(\mathrm{T}_{7}\right)$ recorded high protein content $(15.37 \%)$. Highest chlorophyll content in leaves $(1.45 \mathrm{mg} / \mathrm{g})$ was found in $\mathrm{T}_{2}(100 \% \mathrm{RDF}+\mathrm{FYM} 1.5 \mathrm{t} / \mathrm{ha})$, T3 $(\mathrm{RDF}$ $(75 \%)+$ Azotobacter + Azospirillum + PSB $2 \mathrm{~kg} / \mathrm{ha}$ each) and $\mathrm{T}_{9}(\mathrm{RDF}(50 \%)+(25 \%) \mathrm{N}$ through $\mathrm{FYM}+(25 \%) \mathrm{N}$ through poultry manure). High Ascorbic acid content $(15.26 \mathrm{mg} / 100 \mathrm{~g})$ was found in $\mathrm{T}_{12}(25 \% \mathrm{~N}$ through FYM $+(25 \%) \mathrm{N}$ through vermicompost $+(25 \%) \mathrm{N}$ through poultry manure + $(25 \%) \mathrm{N}$ through neem oil cake + sea weed extract $(15 \mathrm{~kg} / \mathrm{ha})$ which was at par with $\mathrm{T}_{7}(14.31$ $\mathrm{mg} / 100 \mathrm{~g})$. Low crude fibre content $(10.74 \%)$ was observed in $\mathrm{T}_{1}(100 \% \mathrm{RDF})$ followed by $\mathrm{T}_{7}$ $(10.92 \%)$ and $\mathrm{T}_{5}(11.02 \%)$. High TSS content $\left(3.66^{\circ} \mathrm{Brix}\right)$ was found in $\mathrm{T}_{2}$ receiving RDF $(100 \%)$ and FYM (1.5kg/ha).
\end{abstract}

\section{Introduction}

Okra [Abelmoschus esculentus (L). Moench] belonging to family Malvaceae $(2 \mathrm{n}=130)$ commonly known as Bhindi, Gumbo and Lady's finger is a popular fruit vegetable grown round the year and fetches premium price in the market. Besides the utility of its tender green fruits as vegetable, it is used in soups and curries. Okra fruits are canned green or dried for use by army at high altitudes and are also exported helping in earning foreign exchange. In Odisha okra is grown all the thirty districts as a main crop in summer and rainy season and to some extent also in winter and also fetches premium prices in the market. The production of okra is comparatively low due to injudicious 
application of inorganic and organic fertilizers and high incidence of disease and pest. Nutritional imbalances in the soil cause instability in productivity \&hidden hunger of nutrient besides resulting in poor nutritional quality of vegetable. The maintenance of sustainability in production through integrated use of different sources of nutrients also help to maintain the fertility of soil and avoids depletion of soil organic matter and plant nutrients besides suppression of some insect, pest and diseases. Integrated nutrient management (INM) system envisages use of organic manures, green manures, biofertilizers along with chemical fertilizers. From the stand point of crop yield and quality, nutrient supply from both organic and inorganic sources is important. The INM help to store and sustain soil fertility and crop productivity. It may also help to check the emerging deficiency of nutrient other than $\mathrm{N}$, $\mathrm{P}$ and $\mathrm{K}$. In the present Indian Agriculture, keeping in view the inadequate availability of organic sources of nutrients and expected yield decline at least in the initial years, complete substitution of chemical fertilizer is not necessarily warranted. Rather organic sources should be used as partial replacement of the chemical fertilizer. Thus, a strategy for judicious combination of both organic and inorganic sources of nutrient is the most viable option for nutrient management in okra. It will be economically viable and also help in attaining sustainability in production and maintaining soil health and environment. The use of organic amendments applied to soil not only enhances its nutrient status but also reduces the incidence of pest (Adilakshmi et al., 2008).

\section{Materials and Methods}

A field experiment was conducted at the instructional farm of Krishi Vigyan Kendra Jajpur, Odisha during 2015 to study the effect of integrated nutrient management on growth, yield and quality of okra, variety-Pusa A4. The experiment was laid out in randomized block design (RBD) with three replications and twelve treatments. Treatments involved were $\mathrm{T}_{1}(100 \% \mathrm{RDF}), \mathrm{T}_{2}(100 \% \mathrm{RDF}+\mathrm{FYM}$ $1.5 \mathrm{t} / \mathrm{ha}), \mathrm{T}_{3}(\mathrm{RDF}(75 \%)+$ Azotobacter + Azospirillum + PSB (2kg/ha each), $\mathrm{T}_{4}$ (RDF $(75 \%)+(25 \%) \mathrm{N}$ through FYM), $\mathrm{T}_{5}(\mathrm{RDF}$ $(75 \%)+(25 \%) \mathrm{N}$ through vermicompost), $\mathrm{T}_{6}$ $(\mathrm{RDF}(75 \%)+(25 \%) \mathrm{N}$ through poultry manure), $\mathrm{T}_{7}(\mathrm{RDF}(75 \%)+(25 \%) \mathrm{N}$ through neem oil cake), $\mathrm{T}_{8}(\mathrm{RDF}(50 \%)+(25 \%) \mathrm{N}$ through $\mathrm{FYM}+(25 \%) \mathrm{N}$ through vermicompost), $\mathrm{T}_{9}(\mathrm{RDF}(50 \%)+(25 \%) \mathrm{N}$ through $\mathrm{FYM}+(25 \%) \mathrm{N}$ through poultry manure), $\mathrm{T}_{10}(\mathrm{RDF}(50 \%)+(25 \%) \mathrm{N}$ through $\mathrm{FYM}+(25 \%) \mathrm{N}$ through neem oil cake), $\mathrm{T}_{11}$ $(25 \% \mathrm{~N}$ through FYM $+25 \% \mathrm{~N}$ through vermicompost $+25 \% \mathrm{~N}$ through poultry manure $+25 \% \mathrm{~N}$ through neem oil cake), $\mathrm{T}_{12}$ $(25 \% \mathrm{~N}$ through FYM $+25 \% \mathrm{~N}$ through vermicompost $+25 \% \mathrm{~N}$ through poultry manure $+25 \% \mathrm{~N}$ through neem oil cake + sea weed extract $15 \mathrm{~kg} / \mathrm{ha}$ ), where $\mathrm{RDF}$ was recommended dose of fertilizers (110:50:80 NPK $\mathrm{kg} / \mathrm{ha}$.) The land was brought to a fine tilth through ploughing and tillage. Irrigation channels and bunds were prepared according to layout. The seeds were soaked overnight and sown in the field directly. Light irrigation was given just after sowing of seeds. Organic manures were applied one week before sowing.

Full dose of phosphorus, potassium and half dose of nitrogen as per treatments were applied just before sowing. The remaining half dose of nitrogen was applied twenty five days after sowing. All cultural practices were followed regularly during crop growth and observations were recorded on yield and yield attributing characters.

The data on these parameters were subjected to statistical analysis to draw logical conclusions. 


\section{Results and Discussion}

It was observed that yield as well as yield attributing characters like plant height, inter node length, number of nodes per plant, fruit length, girth of fruit, fruit number, fruit weight, yield per plot, yield per ha. Were significantly influenced by different treatments.

Application of nutrients through combinations of organic and inorganic manures were proved beneficial increasing growth, yield as well as quality of okra (Table 1 and 2).

\section{Growth parameters}

\section{Plant height (cm)}

The plant height was maximum in $\mathrm{T}_{7}(131.40$ $\mathrm{cm}$ ) where $75 \% \mathrm{RDF}$ and $25 \% \mathrm{~N}$ through neem oil cake were applied and was at par with $\mathrm{T}_{5}(128.84 \mathrm{~cm})$ and $\mathrm{T}_{10}(119.82 \mathrm{~cm})$. The plant height was found lowest in $\mathrm{T}_{11}(94.86$ $\mathrm{cm})$ where $25 \% \mathrm{~N}$ through FYM $+25 \% \mathrm{~N}$ through vermicompost $+25 \% \mathrm{~N}$ through poultry manure $+25 \% \mathrm{~N}$ through neem oil cake were applied.

Increase in plant height observed in $\mathrm{T}_{7}$ was due to supply of $75 \%$ RDF through chemical fertilizer and $25 \% \mathrm{~N}$ through neem oil cake which resulted in less incidence of sucking pest and disease occurrence for which the source-sink relation and photosynthesis was somewhat normal resulting in increase in plant height. Initial requirement of $\mathrm{N}$ met from the inorganic source and subsequent requirement of $\mathrm{N}$ from organic source assuring continuous $\mathrm{N}$ supply throughout growing period favours consistent $\mathrm{N}$ uptake by plant at different growth stage favouring increase in height.

The present findings corroborate with the findings of Anand et al., (2016), Choudhury et al., (2015) and Das et al., (2014).

\section{Internode length (cm)}

Minimum internode length $(6.67 \mathrm{~cm})$ was recorded in $\mathrm{T}_{11}$. whereas, maximum was found in $\mathrm{T}_{7}(8.02 \mathrm{~cm}) . \mathrm{T}_{7}(8.02 \mathrm{~cm})$ and $\mathrm{T}_{5}(7.80 \mathrm{~cm})$ were at par for this character but significantly differed from other treatments. In the experiment $\mathrm{T}_{10}, \mathrm{~T}_{2}, \mathrm{~T}_{1}, \mathrm{~T}_{8}, \mathrm{~T}_{9}$ recorded internode length of $7.42 \mathrm{~cm}, 7.32 \mathrm{~cm}, 7.22 \mathrm{~cm}$, $7.18 \mathrm{~cm}$ and $7.14 \mathrm{~cm}$ respectively. This might be attributed due to less incidence of disease and pest, synergetic effect of organic and inorganic fertilizer combinations which could make available different nutrients in the soil to the plant and enhanced steady supply of essential nutrient to the crop and favourable soil physical environment. Similar results were obtained by Adilakshmi et al., (2008) and Sharma et al., (2014).

\section{Number of nodes per plant}

The number of nodes per plant varied from 15.14 to 22.42 . Maximum number of nodes (22.42) per plant was recorded in $\mathrm{T}_{5}$ whereas, minimum (15.14) was recorded in $\mathrm{T}_{11}$. $\mathrm{T}_{5}$ was found significant over all other treatments for number of nodes per plant.

Treatments like $\mathrm{T}_{7}$ produced 20.64 nodes per plant followed by 19.42 nodes per plant in $\mathrm{T}_{2}$, 19.25 nodes per plant in $T_{10}$ and 18.62 nodes per plant in $T_{6}$. This is due to better availability and uptake of plant nutrients, more specially $\mathrm{N}, \mathrm{P}, \mathrm{K}$ resulting in better photosynthesis and protein synthesis.

Thus, these increased amount of NPK nutrients in plants, lead to increase plant metabolites that help to build up plant tissues of okra (Prabhu et al., 2003).

The present finding is in accordance with same type of results obtained by Barani and Anburani (2004), Bairwa et al., (2009), Kumar et al., (2013), 


\section{Fruit length}

Maximum fruit length of $11.96 \mathrm{~cm}$ was recorded in $\mathrm{T}_{7}$ and minimum $8.80 \mathrm{~cm}$ in $\mathrm{T}_{11}$. There was significant difference in fruit length observed during the experiment in different treatments. $\mathrm{T}_{7}(11.96 \mathrm{~cm})$ and $\mathrm{T}_{5}(11.32 \mathrm{~cm})$ were found to be at par but significantly different in fruit length as compared to other treatments. $\mathrm{T}_{10}$ produced fruit length of 11.08 $\mathrm{cm}$ followed by $\mathrm{T}_{2}(11.02 \mathrm{~cm})$ and $\mathrm{T}_{6}(10.82$ $\mathrm{cm})$ respectively.

This is in general agreement with report of Santi and Vijaykumari (2005), Bodamwal et al., (2006) and Bairwa et al., (2009).

\section{Fruit number}

Minimum number of fruits was recorded in $\mathrm{T}_{11}$ (10.42) whereas, maximum number of fruits were found with $\mathrm{T}_{7}$ (14.42). Treatment $\mathrm{T}_{7}$ (14.42) and $\mathrm{T}_{5}$ (13.64) were at par for this character. Treatments like $\mathrm{T}_{10}, \mathrm{~T}_{2}$, and $\mathrm{T}_{6}$ recorded 13.15, 13.10 and 13.02 number of fruits per plant respectively. The increased in number of fruits per plant might be due to the better availability and uptake of nutrients by plants. Integrated use of $75 \%$ RDF through chemical fertilizer $+25 \% \mathrm{~N}$ through neem oil cake or vermicompost improved the physical properties of soil and thereby improved the water and nutrient holding capacity of soil as well as soil fertility condition (Subba Rao and Shankar, 2001). Availability of nutrients helps the plant to bear more number of flowers and reduces the chances of flower drop resulting in more number of fruits per plant. The present findings corroborate with the findings of Bodamwal et al., (2006), Munikrishnapa and Tirakannanavan, (2009) and Bairwa et al., (2009).

Table.1 Effect of inorganic as well as organic manures on yield and yield attributing characters of okra

\begin{tabular}{|c|c|c|c|c|c|c|c|c|c|}
\hline $\begin{array}{c}\text { Treatmen } \\
\mathbf{t}\end{array}$ & $\begin{array}{c}\text { Plant } \\
\text { height } \\
\text { (cm) }\end{array}$ & $\begin{array}{c}\text { Inter } \\
\text { node } \\
\text { length } \\
\text { (cm) }\end{array}$ & $\begin{array}{c}\text { Number } \\
\text { of nodes }\end{array}$ & $\begin{array}{c}\text { Fruit } \\
\text { length } \\
\text { (cm) }\end{array}$ & $\begin{array}{c}\text { Fruit } \\
\text { girth } \\
\text { (cm) }\end{array}$ & $\begin{array}{c}\text { Fruit } \\
\text { number }\end{array}$ & $\begin{array}{c}\text { Fruit } \\
\text { weight } \\
\text { (g) }\end{array}$ & $\begin{array}{c}\text { Yield/ } \\
\text { Plot } \\
\text { (kg) }\end{array}$ & $\begin{array}{c}\text { Yield/ } \\
\text { ha } \\
(\mathbf{t o n})\end{array}$ \\
\hline $\mathbf{T}_{\mathbf{1}}$ & 114.25 & 7.22 & 18.14 & 10.63 & 5.61 & 12.84 & 13.19 & 11.88 & 8.48 \\
\hline $\mathbf{T}_{\mathbf{2}}$ & 118.00 & 7.32 & 19.42 & 11.02 & 5.80 & 13.10 & 13.95 & 12.40 & 8.86 \\
\hline $\mathbf{T}_{\mathbf{3}}$ & 102.53 & 6.82 & 16.02 & 9.98 & 5.46 & 11.03 & 12.80 & 10.51 & 7.50 \\
\hline $\mathbf{T}_{\mathbf{4}}$ & 110.95 & 6.94 & 17.20 & 10.27 & 5.52 & 12.21 & 13.03 & 11.25 & 8.03 \\
\hline $\mathbf{T}_{\mathbf{5}}$ & 128.84 & 7.80 & 22.42 & 11.32 & 5.86 & 13.64 & 14.63 & 12.63 & 9.02 \\
\hline $\mathbf{T}_{\mathbf{6}}$ & 115.4 & 7.00 & 18.62 & 10.82 & 5.83 & 13.02 & 13.42 & 12.00 & 8.57 \\
\hline $\mathbf{T}_{\mathbf{7}}$ & 131.40 & 8.02 & 20.64 & 11.96 & 5.83 & 14.42 & 14.89 & 13.29 & 9.49 \\
\hline $\mathbf{T}_{\mathbf{8}}$ & 113.45 & 7.18 & 17.45 & 10.55 & 5.54 & 12.66 & 13.11 & 11.58 & 8.27 \\
\hline $\mathbf{T}_{\mathbf{9}}$ & 106.42 & 7.14 & 16.25 & 10.13 & 5.50 & 11.93 & 12.96 & 11.08 & 7.91 \\
\hline $\mathbf{T}_{\mathbf{1 0}}$ & 119.82 & 7.42 & 19.25 & 11.08 & 5.81 & 13.15 & 14.10 & 12.50 & 8.93 \\
\hline $\mathbf{T}_{\mathbf{1 1}}$ & 94.86 & 6.67 & 15.14 & 8.80 & 5.41 & 10.42 & 12.62 & 9.28 & 6.62 \\
\hline $\mathbf{T}_{\mathbf{1 2}}$ & 97.49 & 6.92 & 15.23 & 8.96 & 5.43 & 10.98 & 12.71 & 9.46 & 6.76 \\
\hline $\mathbf{S E}(\mathbf{m}) \mathbf{\pm}$ & 4.76 & 0.17 & 0.58 & 0.41 & 0.11 & 0.39 & 0.39 & 0.40 & 0.28 \\
\hline $\mathbf{C D}(\mathbf{0 . 0 5})$ & 13.96 & 0.50 & 1.71 & 1.19 & 0.33 & 1.13 & 1.15 & 1.18 & 0.84 \\
\hline
\end{tabular}


Table.2 Effect of inorganic as well as organic manures on quality of okra

\begin{tabular}{|c|c|c|c|c|c|}
\hline Treatment & $\begin{array}{c}\text { Chlorophyll } \\
(\mathbf{m g} / \mathbf{g})\end{array}$ & $\begin{array}{c}\text { Ascorbic acid } \\
(\mathbf{m g} / \mathbf{1 0 0 g})\end{array}$ & $\begin{array}{c}\text { Crude } \\
\text { protein }(\mathbf{\%})\end{array}$ & $\begin{array}{c}\text { Crude fibre } \\
(\mathbf{\%})\end{array}$ & TSS $\left({ }^{\mathbf{0}} \mathbf{B r i x}\right)$ \\
\hline $\mathbf{T}_{\mathbf{1}}$ & 1.34 & 12.24 & 14.12 & 10.74 & 2.86 \\
\hline $\mathbf{T}_{\mathbf{2}}$ & 1.45 & 13.82 & 14.68 & 12.88 & 3.66 \\
\hline $\mathbf{T}_{\mathbf{3}}$ & 1.45 & 13.26 & 13.31 & 12.18 & 3.27 \\
\hline $\mathbf{T}_{\mathbf{4}}$ & 1.34 & 12.81 & 13.75 & 11.64 & 2.54 \\
\hline $\mathbf{T}_{\mathbf{5}}$ & 1.42 & 13.41 & 15.12 & 11.02 & 2.64 \\
\hline $\mathbf{T}_{\mathbf{6}}$ & 1.34 & 12.16 & 14.50 & 11.76 & 3.08 \\
\hline $\mathbf{T}_{\mathbf{7}}$ & 1.43 & 14.31 & 15.37 & 10.92 & 3.06 \\
\hline $\mathbf{T}_{\mathbf{8}}$ & 1.34 & 14.91 & 13.93 & 12.68 & 2.72 \\
\hline $\mathbf{T}_{\mathbf{9}}$ & 1.45 & 13.56 & 13.43 & 12.60 & 2.84 \\
\hline $\mathbf{T}_{\mathbf{1 0}}$ & 1.40 & 13.72 & 14.87 & 11.24 & 3.42 \\
\hline $\mathbf{T}_{\mathbf{1 1}}$ & 1.30 & 14.84 & 13.12 & 11.62 & 3.36 \\
\hline $\mathbf{T}_{\mathbf{1 2}}$ & 1.23 & 15.26 & 13.25 & 11.92 & 3.06 \\
\hline $\mathbf{S E}(\mathbf{m}) \mathbf{\pm}$ & 0.02 & 0.32 & 0.28 & 0.42 & 0.09 \\
\hline $\mathbf{C D}(\mathbf{0 . 0 5})$ & 0.04 & 0.95 & 0.83 & 1.24 & 0.25 \\
\hline
\end{tabular}

\section{Girth of fruit (cm)}

In the experiment $T_{5}$ produced fruits with maximum girth $(5.86 \mathrm{~cm})$ followed by $\mathrm{T}_{7}$ $(5.83 \mathrm{~cm})$ and $\mathrm{T}_{6}(5.83 \mathrm{~cm})$ respectively. It was minimum in $\mathrm{T}_{11}(5.41 \mathrm{~cm})$. This might be attributed to the synergistic effects of organic manures which make more nutrients available to the plants by improving the soil physical condition and solubilizing the nutrients in soil. The increased vegetative growth, balanced $\mathrm{C} / \mathrm{N}$ ratio and increased synthesis of carbohydrates help in increasing the fruit size. Similar findings were reported by Bodamwal et al., (2006), Bairwa et al., (2009) and Shelar et al., (2011).

\section{Fruit weight (g)}

Highest fruit weight of $14.89 \mathrm{~g}$ was recorded $\mathrm{T}_{7}$ and lowest of $12.62 \mathrm{~g}$ was observed in $\mathrm{T}_{11}$. It was observed that $\mathrm{T}_{7}(14.89 \mathrm{~g}), \mathrm{T}_{5}(14.63 \mathrm{~g})$ and $\mathrm{T}_{10}(14.10 \mathrm{~g})$ were at par for this character. Combined application of organic and inorganic fertilizer increase the availability and uptake of more plant nutrients resulting in luxuriant vegetative growth. The increased photosynthetic area and translocation of photosynthetics in plants subsequently accelerated the formulation of more number of large sized fruits with more number of seeds per fruits resulting in increase in fruit weight. Similar results for okra were also reported by Bairwa et al., (2009), Shelar et al., (2011), Wagh et al., (2014) in okra.

\section{Fruit yield}

Fruit yield was maximum in $\mathrm{T}_{7}(13.29 \mathrm{~kg})$ and minimum in $\mathrm{T}_{11}(9.28 \mathrm{~kg}) . \mathrm{T}_{7}(13.29 \mathrm{~kg})$ was highly significant over all treatments except $\mathrm{T}_{5}(12.63 \mathrm{~kg})$ which was at par with other. Other treatments like $\mathrm{T}_{10}, \mathrm{~T}_{2}$ and $\mathrm{T}_{6}$ recorded yield of $12.50 \mathrm{~kg}, 12.40 \mathrm{~kg}, 12.00 \mathrm{~kg}$ per plot respectively. Fruit yield per hectare varied significantly and was maximum with $T_{7}$ (9.49ton) and was minimum with $\mathrm{T}_{11}$ (6.62ton). $\mathrm{T}_{7}$ (9.49 ton) and $\mathrm{T}_{5}$ (9.02ton) were at par with each other and statistically significant to all other treatments. It was evident from the present study that 
application of neem oil cake proved to be very significant in reducing incidence of disease and pest. The efficacy of neem cake in reducing incidence of pest in okra reported by Godase and Patel, 2001, Mallick and Lal, 1989 and Tripathy et al., 2009. Application of neem oil cake along with chemical fertilizer significantly increased the number of fruits per plant, fruit weight which result in increasing yield. This is due to the better availability and uptake of plant nutrients for a longer time of crop growth due to neem cake as compared to other combination of fertilizer. Similar type of results were also reported by Bairwa et al., (2009), Prasad and Naik, (2013), Mal et al., (2014), Choudhary et al., (2015), Das et al., (2014), Anand et al., (2016) and Kumar et al., (2017) in okra.

\section{Quality parameters}

\section{Leaf chlorophyll}

Leaf chlorophyll content was influenced by combined application of inorganic fertilizers along with organic manures in the form of neem oil cake, poultry manure, vermicompost, FYM, biofertilizer and sea weed extract. Leaf chlorophyll content was maximum in $\mathrm{T}_{2}, \mathrm{~T}_{3}$ and $\mathrm{T}_{9}(1.45 \mathrm{mg} / \mathrm{g})$ followed by $\mathrm{T}_{7}(1.43 \mathrm{mg} / \mathrm{g})$ and $\mathrm{T}_{5}(1.42$ $\mathrm{mg} / \mathrm{g})$ and was minimum in $\mathrm{T}_{12}(1.23 \mathrm{mg} / \mathrm{g})$. Treatments $\mathrm{T}_{2}(1.45 \mathrm{mg} / \mathrm{g}), \mathrm{T}_{3}(1.45 \mathrm{mg} / \mathrm{g}), \mathrm{T}_{9}$ (1.45 mg/g), $\mathrm{T}_{7}(1.43 \mathrm{mg} / \mathrm{g})$ and $\mathrm{T}_{5}(1.42$ $\mathrm{mg} / \mathrm{g}$ ) were at par. Similar result were obtained Bairwa et al., 2009, Shanti and Vijayakumari (2005) and Sharma and Choudhary (2011).

\section{Ascorbic acid content}

The present investigation revealed that ascorbic acid content in okra varied significantly with treatments. Maximum ascorbic acid content was found in $\mathrm{T}_{12}(15.26$ $\mathrm{mg} / 100 \mathrm{~g})$ ) and found at par with $\mathrm{T}_{8}(14.91$ $\mathrm{mg} / 100 \mathrm{~g}), \mathrm{T}_{11}(14.84 \mathrm{mg} / 100 \mathrm{~g})$ and $\mathrm{T}_{7}$ $(14.31 \mathrm{mg} / 100 \mathrm{~g})$ and was minimum in $\mathrm{T}_{6}$ $(12.16 \mathrm{mg} / 100 \mathrm{~g})$. Similar findings of increased ascorbic acid content of okra fruits with combined application of organic and inorganic fertilizers were also reported by Tripathy et al., (2009), Ciba et al., (2017) and Singh et al., 2018 in okra.

\section{Crude protein}

The crude protein content was maximum in $\mathrm{T}_{7}(15.37 \%)$ and was minimum in $\mathrm{T}_{11}(13.12$ $\%) . \mathrm{T}_{7}(15.37 \%), \mathrm{T}_{5}(15.12 \%), \mathrm{T}_{10}(14.87 \%)$ and $\mathrm{T}_{2}(14.68 \%)$ were at par for this character. Variation in protein content in okra fruit due to different INM practices were also reported by Raj and Geethakumari (2001) and Wagh et al., (2014) in okra.

\section{Crude fibre content}

Crude fibre content is one of the important criteria to judge the quality of okra pod. Maximum crude fibre in fruit was found in $\mathrm{T}_{2}$ $(12.88 \%)$ and minimum in $\mathrm{T}_{1}(10.74 \%)$. $\mathrm{T}_{1}$ $(10.74 \%), \mathrm{T}_{7}(10.92 \%), \mathrm{T}_{5}(11.02 \%), \mathrm{T}_{10}$ (11.24\%), $\mathrm{T}_{4}(11.64 \%), \mathrm{T}_{6}(11.76 \%), \mathrm{T}_{11}$ $(11.62 \%)$ and $\mathrm{T}_{12}(11.92 \%)$ were at par. The crude fibre content increased with the advancement of crop growth. It might be due to reduced succulence resulting from the cell wall thickening and reduced uptake of nitrogen with advancement of crop growth. The present findings corroborate with Wagh et al., (2014), Ciba et al., (2017) and Amiry et al., (2018) in okra.

\section{Total soluble solid (TSS)}

Total soluble solid (TSS) of fruit was found maximum in $\mathrm{T}_{2}\left(3.66^{\circ}\right.$ Brix $)$ followed by $\mathrm{T}_{10}$ (3.42 ${ }^{\circ}$ Brix), $\mathrm{T}_{11}\left(3.36{ }^{\circ}\right.$ Brix) and was minimum in $\mathrm{T}_{4}\left(2.54{ }^{\circ} \mathrm{Brix}\right)$. This result was in conformation with Singh et al., (2018) and Amiry et al., (2018) in okra. 
From the experimental result it was observed that integrated application of $75 \%$ RDF in the form of chemical fertilizers and $25 \% \mathrm{~N}$ through neem oil cake was found best in producing more plant height. Internode length, number of nodes per plant, fruit length, fruit girth, number of fruits per plant, fruit weight, yield per plot with higher yield and also increased quality of fruit in okra.

\section{References}

Adilakshmi, A., Korat, D.M. and Vaishnav, P.R. 2008. Effect of organic manures and inorganic fertilizers on insect pests infesting okra. Karnataka J. of Agric. Sci. 21(2): 287-289.

Amiry, Mohammad Nader., Anjanappa, M., Ibaad, M.H., Indiresh, K.M., Patil, S.V., Anil kumar, S. and Ajaneya Reddy, B. 2018. Influence of integrated nutrient management on soil nutrient status, nutrient uptake and quality of okra (Abelmoschus exculentus (L.) Moench.) cv. Arka Anamika under drip irrigation. Int.J.Pure App.Biosci. 6(1): 1012-1015.

Anand, Ballal. and Kadam, A. S. 2016. Okra crop growth and yield responses to different organic sources of nitrogen. Int. J. of Agric. Sci. 8 (48): 2042-2044.

Bairwa, H.L., Shukla, A.K., Mahawer, L.N., Kaushik, R.A., Shukla, K.B. and Ameta, K.D. 2009. Response of integrated nutrient management on yield, quality and physio-chemical characteristics of okra cv. Arka Anamika. Indian J. of Hort. 66(3): 310314.

Barani, P. and Amburani, A. 2004. Influence of vermicomposting on major nutrients in bhendi (Abelmoschus esculentus L. Moench). var. Arka Anamika, South Indian Hort. 52(1-6): 351.354.

Bodamwal, S.G. and Rajput, S.G. 2006. Influence of organic and inorganic fertilizer on seed quality and seed yield of okra cv. Parbhani Kranti. J. of Maharashtra Agric. University, 31(1): 130-131.

Choudhary, K., More, S.J. and Bhandevi, D.R. 2015. Impact of Biofertilizers and chemical fertilizers on growth and yield of okra (Abelmoschus esculentus L. Moench). The Ecoscan, 9(1\&2): 67-70.

Ciba, C. And Syamala, M. 2017. Study on integrated nutrient management on physiological and Biochemical Attributes of okra (Abelmoschus esculentus L. Moench). Int.J.Curr.Microbiol.App.Sci. 6(11): 3321-3325.

Das, A.K., Prasad, B. and Singh, R. 2014. Response of chemical fertilizer and vermicompost on okra (Abelmoschus esculentus) cv. Pravani Kranti. The Asian J. of Hort. 9(2): 372-376.

Godase, S.K. and Patel, C.B.2001. Studies on the influence of organic manures aand fertilizer doses on the intensity of sucking pests (Amrasca biguttula biguttula (Ishida) and Aphid (Aphis gossypii Glover) infesting brinjal. Plant protection Bulletin 53: 10-12.

Kumar, T., Kumar, M., Singh, M., Kumar, K., Kumar, A., Kumar, S. and Singh, B. 2013. Impact of integrated nutrient management (INM) on growth and economic yield of okra. Annals of Horticulture, 6(1): 107-114.

Kumar, V., Saikia, Jumi. and Nath, D.J. 2017.Effect of integrated nutrient management on growth, yield and quality of okra (Abelmoschus esculentus (L). Moench cv. Arka Anamika, Int. J. of chemical studies, 5(5): 2001-2003.

Mal, B, Mahapatra, P. and Mohanty, S. 2014. Effect of Diazotrophs and Chemical fertilizers on production and economics of okra (Abelmoschus esculentus L. Moench.) cultivars. American J. of Plant Sci. 5: 168-174. 
Mallik, S.N. and Lal, I.B. 1989. Efficiency of Neem oil cake and fertilizer mixture against okra fruit borer. Pestology, 13: 6-7.

Munikrishnappa, P.M. and Tirakannanavar, S. 2009. Effect of organic and inorganic fertilizer on growth and yield of bhendi (Abelmoschus esculentus). J. of Eco-biology 25(4:349-354.

Prabhu, T., Narwadekar, P.R., Sannindranath, A.K. and Rabi, M. 2003. Effect of integrated nutrient management on growth and yield of okra (Abelmoschus esculentus (L.) Moench) cv. Parbhani Kranti, Orissa J. of Hort. 31(1): 17-21.

Prasad, P.H. and Naik, A. 2013. Effect of varying NPK levels and Biofertilizers on growth and yield of okra (Abelmoschus esculentus L. Moench) under sustainable condition. Trends in Biosciences, 6(2): 167-169.

Raj, A.K. and Geethakumari, V.L. 2001. Effect of organic manures and azospirillum inoculation on yield and quality of okra (Abelmoschus exculentus L. Moench). Veg. Sci. 28(2): 179-181.

Shanti, N. and Vijayakumari, B. 2005. Influence of NPK with different organic manures on yield attributes of bhendi (Abelmoschus esculentus). J. of Ecobiology, 17(1): 49-54.

Sharma, D.P., Prajapat, J. and Tiwari, A. 2014. Effect of NPK, vermicompost and vermiwash on growth and yield of okra. Int. J. of Basic and App. Agric. Res. 12(1): 5-8.
Sharma, G.R. and Choudhury, M.R. 2011 Effect of integrated nutrient management on growth, yield and quality of okra (Abelmoschus esculentus L. Moench). M. Sc. (Ag.) thesis submitted to Swami Keshwanand Rajasthan Agricultural University, Bikaner.

Shelar, R.B., Kadam, A.S., Patil, V.K. and Narsude, P.B. 2011. Studies on effect of different sources of nitrogen on growth and yield of okra (Abelmoschus esculentus L. Moench). Int. J. of Agric. Sci. 7(1): 70-73.

Singh, Smriti. And Ram, R.B. 2018.Biochemical study on Kashi Pragati of Okra cultivar in respect with organic, inorganic and Biofertilizers. Curr. J. Appl. Sci. Tech. 27(5): 1-5.

Subba Rao, T.S.S. and Sankar, C.R., 2001.Effect of organic manures on growth and yield of Brinjal, South Indian Hort. 49: 288-289.

Tripathy, P., Maity, T.K. and Patnaik H.P. 2009. Fruit constituents of okra cultivars and the incidence of Earias vitella (FAB) as influenced by the integrated nutrient management system. SAARC J.of Agric. 7(2): 82-90.

Wagh, S.S., Laharia, G.S., Iratakar, A.G. and Gajare, A.S. 2014. Effect of INM on nutrient uptake, yield and quality of okra (Abelmoschus esculentus L. Moench. An Asian J. of Soil Sci. 9(1): 21-24.

\section{How to cite this article:}

Mishra, B., G.S. Sahu, P. Tripathy, S. Mohanty and Pradhan, S. 2019. Effect of Organic and Inorganic Fertilizers on Growth, Yield and Quality of Okra under Integrated Nutrient Management. Int.J.Curr.Microbiol.App.Sci. 8(08): 66-73. doi: https://doi.org/10.20546/ijcmas.2019.808.008 